\title{
Utilizing platforms in industrialized construction
}

\section{A case study of a precast manufacturer}

\author{
Bonev, Martin; Wörösch, Michael; Hvam, Lars
}

\section{Published in:}

Construction Innovation

Link to article, DOI:

10.1108/Cl-04-2014-0023

Publication date:

2015

Document Version

Peer reviewed version

Link back to DTU Orbit

Citation (APA):

Bonev, M., Wörösch, M., \& Hvam, L. (2015). Utilizing platforms in industrialized construction: A case study of a precast manufacturer. Construction Innovation, 15(1), 84-106. https://doi.org/10.1108/Cl-04-2014-0023

\section{General rights}

Copyright and moral rights for the publications made accessible in the public portal are retained by the authors and/or other copyright owners and it is a condition of accessing publications that users recognise and abide by the legal requirements associated with these rights.

- Users may download and print one copy of any publication from the public portal for the purpose of private study or research.

- You may not further distribute the material or use it for any profit-making activity or commercial gain

- You may freely distribute the URL identifying the publication in the public portal

If you believe that this document breaches copyright please contact us providing details, and we will remove access to the work immediately and investigate your claim. 


\title{
Utilising Platforms in Industrialised Construction: A Case Study of a Precast Manufacturer
}

\begin{abstract}
Purpose - Offering custom tailored buildings at reasonable costs has been a growing concern to many construction companies. A promising approach adapted by operations management and design theory regards individual building projects as the adjustment and recombination of components and processes from a set of predefined platforms, while configuration systems assure feasible building solutions. The aim of this paper is to explore the development of a platform-based project execution in the industrialised construction sector, with a focus on systematically balancing for cost and value.
\end{abstract}

Design/methodology/approach - After adapting some of the underlying assertions of platform design to the engineer-to-order situation in construction, the practical implications are evaluated on a case study of a precast manufacturer using high performance concrete.

Findings - Based on empirical findings from three distinct platform strategies, this research highlights key aspects of adapting platform-based developed theory to industrialised construction. Building projects employ different layers of product, process and logistics platforms to form the right cost-value ratio for the target market application, while modelling methods map structural platform characteristics so as to balance commonality and distinctiveness.

Originality/value - This paper proposes a general theory of platform-based development and execution in the industrialised construction sector, which goes beyond concurrent approaches of standardising and systemising buildings projects. It adapts and extends established frameworks for platform development to the engineer-to-order situation in construction and empirically validates their cost and value effects.

Keywords Industrialised construction, Engineer-to-order, Platform, Mass customization, Value, Postponement

Paper type Case Study

\section{Introduction}

Various attempts have been made to face the diverse challenges in the building sector. Off-site manufacturing and the creation of systematic procedures and standardised building elements enforced the industrialisation of the sector since the middle of the nineteenth century (Finnimore, 1989). The potential benefits from an industrial building environment are many and diverse (Blismas, Pasquire, \& Gibb, 2006). Zabihi et al. (2013) for example, argue that with off-site manufacturing, capacity and quality could be increased, while simultaneously offering more complex building components at a lower cost. Time related advantages with regard to the production and erection of buildings are for instance discussed by Sacks et al. (2004) and Jaillon and Poon (2009). Other potential improvements involve the reduction of construction waste (Lachimpadi, Pereira, Taha, \& Mokhtar, 2012) and a lower environmental impact as well as higher sustainability performance (Chen, Okudan, \& Riley, 2010).

The delivery of industrialised building systems has more recently been seen as a means for additional productivity advancement (Jansson, Johnsson, \& Engström, 2013; Thuesen \& Hvam, 2011). The building is seen as a set of major systems like walls, roof and foundation, where enterprises within on-site erection and off-site production of products and components mutually contribute to the construction project (Lachimpadi et al., 2012). Thuesen and Hvam (2011) for example investigate how system deliveries can lead to efficiency improvements of the German on-site construction. Their study shows how standardised procedures, preferred building solutions, as well as the reuse of experience and working groups (logistics platforms) have gained significant cost reductions on a number of housing projects without sacrificing- customer value. Similarly Jansson et al. (2013) study the advantage of delivering systems building as opposed to individual components. The authors examine the reuse of common processes and technical solutions across a number of building projects. Their 
effect on the design phase of two case companies has further been discussed in relation to the platform categories defined by Robertson and Ulrich (1998).

Competing with building systems which share common platforms provides a promising alternative to the mere standardisation strategy of traditional industrialised construction. Apart from systemising procedures and reusing technical specifications, in many industries the multi-product strategy of a platform approach has led to additional productivity and flexibility advantages. Early contributions see companies' product structure as a main driver for a platform implementation, emphasising the definition of a product platform as a set of common components or modules from which derivative products can be efficiently developed and launched (Meyer and Lehnerd, 1997). Baldwin and Clark (2000) define three distinct characteristics of a product platform as: (1) a modular architecture, (2) the interfaces, and (3) the standards, which form design rules to which the modules conform. The prevailing approach to platform development is therefore to develop methods, tools and algorithms in support of the physical product family modelling (Yigit et al., 2002). Moreover, Robertson and Ulrich (1998) point out that product platforms represent more than the physical structure of a product, but rather a collection of assets, which are common for a set of products. This holistic view has also been discussed by Jiao et al. (2007). The authors argue that a platform design can be seen as defining a set of common elements along the entire value creation process of a product or project respectively.

\section{Research aim}

The aim of this research is to explore the potential of a platform-based product development approach within industrialised construction, in particular represented by the precast sector as a major actor within the industry (Sacks, Eastman, \& Lee, 2004). The remainder of this paper is formulated as following. First, existing platform frameworks are adapted on the engineer-to-order (ETO) situation of the precast industry. A heuristic view to platform design and modelling for building projects is introduced and its impact on the precast value chain is discussed relative to different manufacturing strategies. Next, a case study of a precast concrete manufacturer is presented, where the proposed methods are being applied and their operational impact on the precast value chain is being discussed. The paper concludes with the benefits and limitations of the proposed approach.

\section{Customising building projects with platforms}

Research in construction has a long tradition in comparing and adapting related approaches from other industry sectors, like car production. Several authors have investigated the potential of such crossindustry learning, where significant benefits on industrialised housing could be proven (Barlow et al., 2003). A key lesson from the automotive industry is the ability to provide a higher degree of customisation without compromising lead times, quality and costs (Parry and Graves, 2008). What became known as mass customization aims at using configuration systems, adjustable product structures, flexible processes and adaptive organisations around a predefined set of platforms to efficiently offer custom-tailored products (Su et al., 2005). To explore the potential for platforms, manufacturing companies are classified according to the customer order decoupling point (CODP), i.e. the degree the manufacturing set-up is customer-independent and based on forecast or order-related and connected to a specific sale (Sharman, 1984). Wikner and Rudberg (2005) categorised the most commonly mentioned strategies throughout literature as engineer-to-order (ETO), make-to-order (MTO), assemble-to-order (ATO), and make-to-stock (MTS). In the context of construction, conceptto-order (CTO) is in addition used to describe a situation in which a customer is strongly involved already at the early conceptual phase of a building project (Winch, 2003). Taking the example of a building, by engaging with e.g. the architect, in a CTO situation the customer then actively shapes the conceptual building scheme from the beginning, without in particular basing his ideas on a predefined structural or feasibility concerns (Mora et al., 2008). Empirical examples can be found in one-off projects, where uniqueness of design is more important than productivity or functionality (Hobday, 2000). In a MTS strategy, on the other hand, the customer enters the process at a very late stage of its value creation. This strategy makes use of market forecasts to convert raw materials and components all the way to final standard products in accordance to expected customer demands. Between those two categories there are MTO and ATO firms which allow a certain degree of customisation based on the standardisation level of their products, like for example the previously mentioned car manufacturers. 


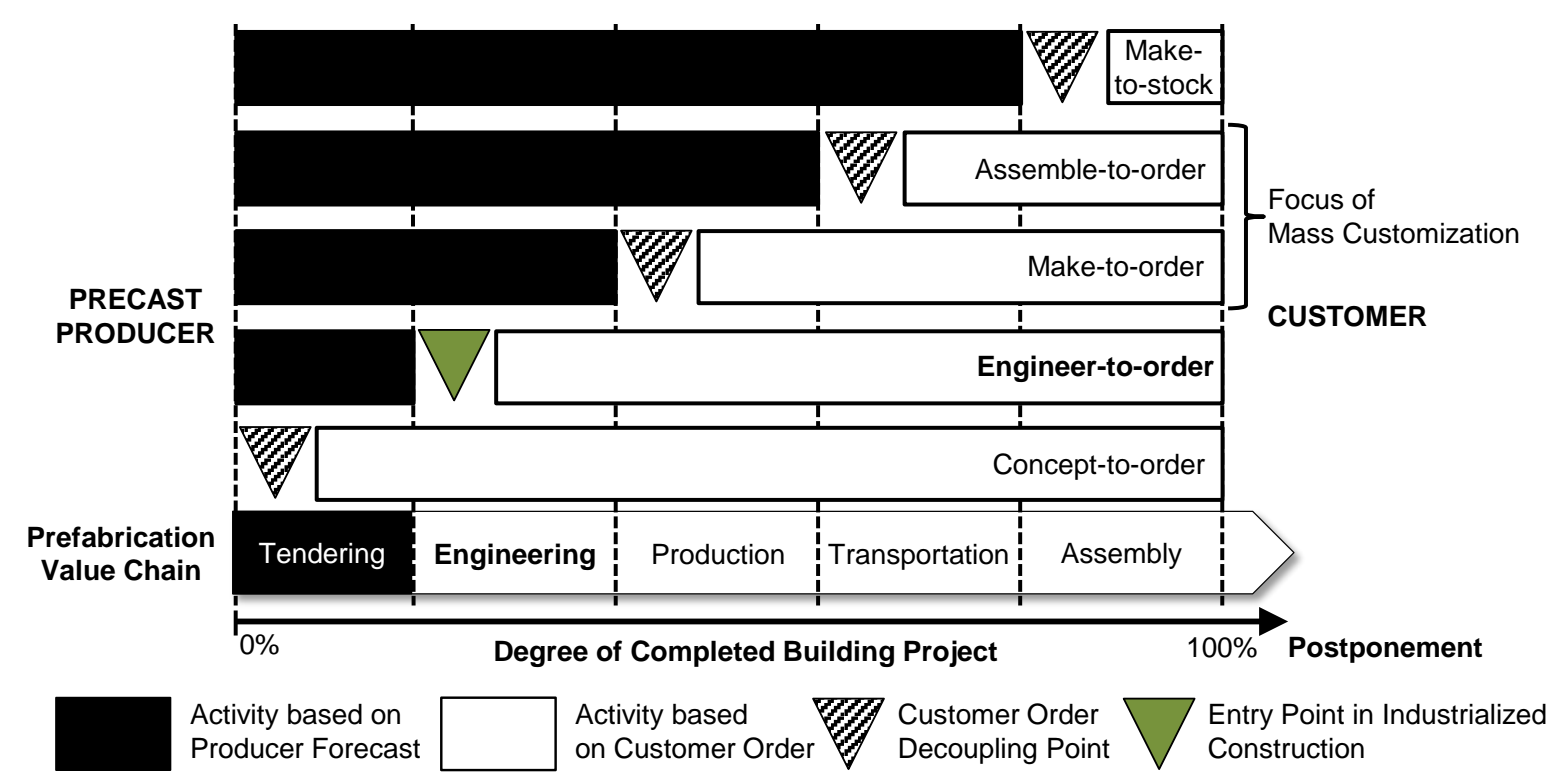

Figure 1: The CODP model in relation to the value chain of a precast manufacturer

In relation to the CODP, the precast supplier can be classified as an ETO manufacturer providing industrialised building systems (Zabihi, Habib, \& Mirsaeedie, 2013). As a common characteristic for ETO firms, the value chain consists of a non-physical stage involving marketing, tendering and engineering activities and a physical stage which concerns production, transportation and on-site assembly (Bertrand \& $\mathrm{Mu}, 1993$ ). The schematic representation in Figure 1 indicates how the customer enters the engineering phase of the value chain after completing the tendering process for a project. Starting from there, all subsequent phases including producing the concrete elements, shipping and assembling them on the construction site, can be directly related to a particular customer or client order.

To achieve mass customization, companies coming from a MTS strategy need to move towards an ATO production (Wortman et al., 1997). On the other hand, ETO companies need to accept a higher level of product and/or process standardisation, while postponing the COPD further down the value chain (Haug et al., 2009). In avoiding this trade-off and moving the equilibrium point to a higher flexibility and productivity level, companies are utilising platform concepts to balance the required level of standardisation, while maintaining the desired flexibility throughout the value chain (J. R. Jiao, Simpson, \& Siddique, 2007). Hence, a key objective of a platform-based product development is to provide sufficient product variety to meet individual customer needs while maintaining economies of scale and scope within manufacturing (Pine, 1993).

\section{Platform modelling framework for building projects}

Figure 2 illustrates a holistic approach to product family design through platforms throughout the value chain of a building project. The framework comprises five domains; customer, functional, physical, process, and logistics domain. The customer domain involves the development of customer insight, where marketing techniques are used to determine customer attributes (CAs), i.e. requirements in relation to the market (Meyer and Lehnerd, 1997). Apart from requirements directly coming from the customer, there are a number of stakeholder requirements and governmental regulations that need to be fulfilled as well (Stevens and Martin, 1995). For ETO firms the nature of the requirements tends to be specific and technical (Rahim \& Baksh, 2003). In the building sector they are often related to the building design and its different levels of details (Kiviniemi, 2005). As building regulations evolve, house builders and off-site manufacturers have to keep compliance and quickly adapt to new demands (Pan, Gibb, \& Dainty, 2007). Once identified, common requirements can be grouped together to form consistent value prepositions for different market segments and to grade the impact the stakeholders have on them (Simpson et al., 2011). CAs are then converted into a minimum set of functional requirements (FRs) in the functional domain as $C A s=\min (\{F R s\})$. Here architects traditionally develop building concepts from the customer information in an architectural design, based on existing industry 
norms and standards and available product technologies. The architectural design includes overall parameters of a building and architectural preferences on e.g. materials, shapes and styles, or increased energy efficiency. In platform terms, this mapping constitutes the definition of a product portfolio with a number of product families through which common practices of order configuration and sales automation with configuration systems are performed (J. R. Jiao et al., 2007).

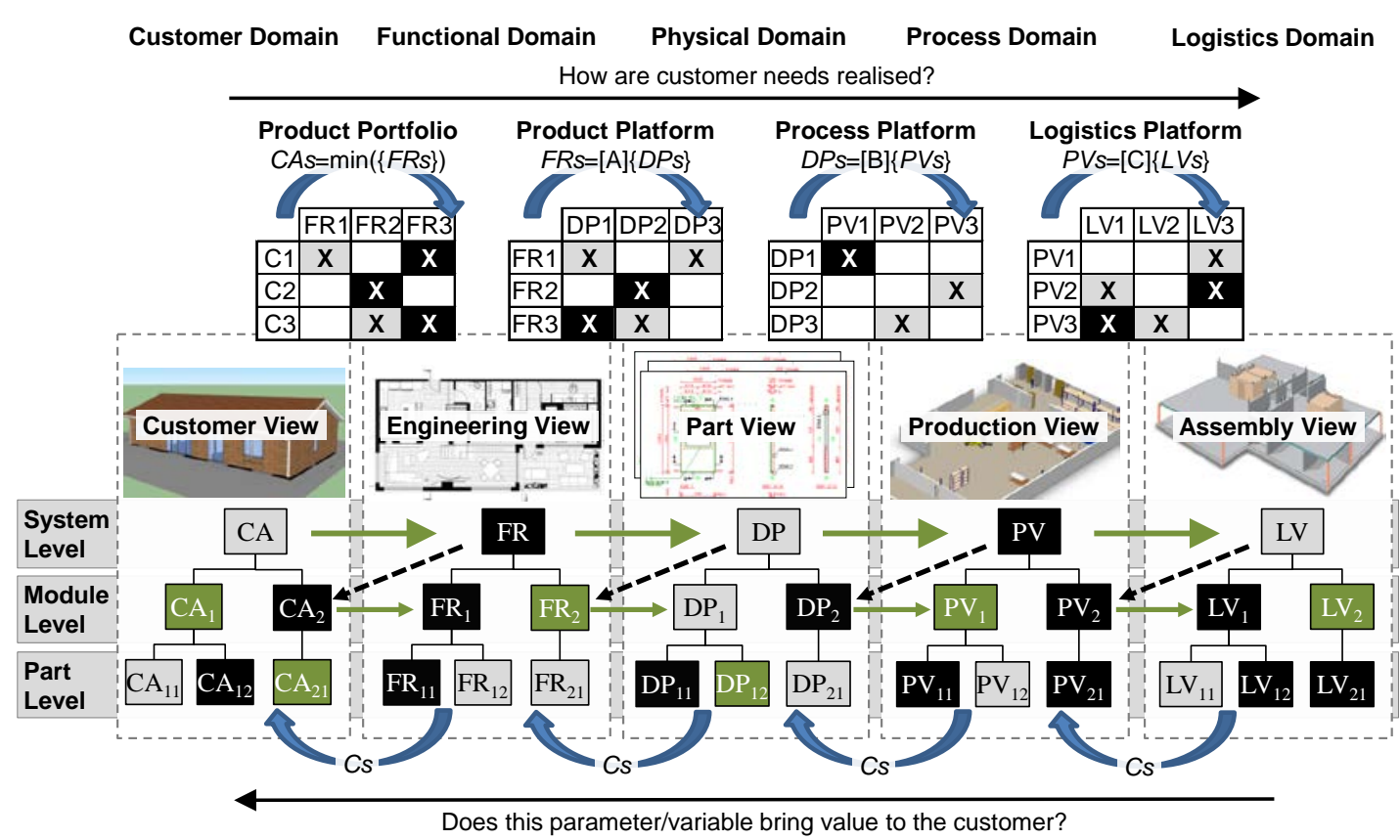

CAs - Customer Attributes FRs - Functional Requirements DPS - Design Parameters PVs - Process Variables LVs - Logistic Variables Cs - Constraints $\square$ Common Element (Part-of) $\square$ Variant (Kind-of) $\square$ Change Propagation of New Requirements

Figure 2: Holistic view on platforms in industrialised construction (adapted from Jiao et al., 2007)

Mapping the relationships and interfaces of FRs to design parameters (DPs) is done in the physical domain and encompasses the definition of a product architecture as $F R s=[A]\{D P s\}$ (Suh, 2001). Engineers transfer the initial design intent of the architect into a structural model with the objective to create feasible structure solutions, while referring to given architectural patterns and constrains. Such decisions are mostly based on the engineer's knowledge and experience of the realisation of the design intents on a given situation. With the structural analysis and the determination of the building behaviour of the preliminary design, the design focus changes from the innovative design intent of the conceptual design to a design task on a routine basis (Mora et al., 2008). A process architecture can be defined accordingly as the mapping of the DPs to process variables (PVs) in form of $D P s=[B]\{P V s\}$ and logistics variables (LVs) as $P V s=[C]\{L V s\}$ respectively. The last two domains traditionally involve the creation of common manufacturing processes, production technologies and distribution networks (Meyer and Lehnerd, 1997). Common production tools, machines, transportation resources and assembly methods can be used to reduce manufacturing set-up risks and to reuse proven production and assembly processes (Sawhney, 1998). From a precast perspective, the main concern is the transformation of design specifications of a building into physical precast elements and their subsequent on-site assembly.

In an ETO situation developing well-functioning relationships among teams and team members is particularly important. Sales, engineering and production activities are traditionally rarely standardised and rely on specific skills and craftsmanship. Extended coordination mechanisms are therefore used to balance product specifications with engineering and production capabilities for all upcoming orders (Konijnendijk, 1994). With the employment of stable teams within each stage of the value creation of a building, the precast producer can expect to benefit from economies of scope. The ability to produce and deliver the created building designs results in constraints, (CSs) which have an upstream effect on the foregoing domains. Precast elements, for example, need to be lifted and assembled at the 
construction site. Build-in lifting brackets and mechanisms for assembly have to be designed and cast in place at the foregoing steps of the product realisation process.

Modelling platforms from different perspectives through the so called views facilitate the consideration of all five domains of a building project (J. Jiao \& Tseng, 1999). As indicated in Figure 2 , generic modelling notations are commonly used to represent hierarchies, commonalties (Part-of structure), alternative varieties (Kind-of structure), and ranges (Jiao and Tseng, 1999). Change propagation effects from newly identified building requirements can then directly be seen within the system (Clarkson et al., 2004). The hierarchical classification of materials, parts, components and subassemblies represents the product structure (Do et al., 2002), and is consistent with the common definition for bill of material (BOM) (Garwood, 1988). The different perspectives and relationships are modelled with the same notation, while their interrelations are mapped through direct connections and constraints for configuration. Most generic modelling approaches follow the basic principles of object oriented modelling using the Unified Modelling Language (UML) (Felfernig et al., 2000). With their help, even complex product architectures, such as for ETO products can be created (Brière-Côté, Rivest, \& Desrochers, 2010). Today existing product lifecycle management (PLM) solutions obtain the same object-oriented hierarchical structure of a product (Mesihovic et al., 2004). The overview of product structures with many component interrelations may be maintained with matrix-based modelling methods (Steward, 1981). The elements of such matrixes are simply listed in columns and rows and connections are made through the matching cells. Over the years, many related modelling methods and tools have been proposed in academia. With their relatively simple notation, Design Structure Matrixes (DSMs) have for example been developed to assess, reorganise, and cluster relationships between functional or physical elements (Eppinger et al., 1994). The methods have been applied on a number of product examples spanning from commercial to industrial products. To represent hierarchies of common and distinct elements in ETO platform designs, the matrix-based models are to be combined with the generic modelling techniques.

\section{Platform effects on engineering}

ETO firms are by definition strongly concerned with engineering activities and how they are to be carried out in combination with manufacturing (Konijnendijk, 1994). To achieve the benefits from the use of platforms, they have to postpone the CODP to a later stage of the value chain, or in other words they have to accept a higher degree of predefinition of the subsequent tasks. Wikner and Rudberg (2005) point out the two-dimensional character of postponement for ETO firms. Apart from the production dimension, postponing the CODP can be seen from the engineering perspective as well. Based on contributions identified in literature, the authors conceptualise the extended two-dimensional framework of the CODP and further describe the characteristics of a possible engineering-production mix in terms of postponement. Precast manufacturers are traditionally characterised as being engineerto-order in the engineering dimension $\left(\mathrm{ETO}_{\mathrm{ED}}\right)$. They use the majority of their engineering resources for making building specifications on individual projects, while complying with industry specific standards and norms. Their products obtain a low number of commonality, as the solution space communicated to their customers contains no explicitly formulated boundaries in form of e.g. catalogues from the beginning. Figure 3 depicts the link between the degree of standardisation from a building system perspective and its potential impact on placing the CODP in engineering.

The lowest level of system standardisation, i.e. formalisation, targets the part and component level. From a precast perspective such components are for example represented by different forms and dimensions of iron bars, insulation materials, concrete recipes etc. The formalisation process includes the creation of a formal product family model containing generic product structures of the domains. Through product development, precast manufacturers need to agree on a common solution space for their product families, where for example, possible precast element dimensions, load bearing capacity, dimension and placement of recesses, or different materials and surfaces are mapped. The objective of this stage is to make an explicit documentation of possible variations, calculations and restrictions for a given family, without necessarily reducing the functionality and respectively the variety given to customers. By formalising the product portfolio, the precast producer is able to reuse the product knowledge on each building project more systematically and adapt-to-order $\left(\mathrm{ATO}_{\mathrm{ED}}\right)$ the building specifications within the boundaries of the established solution space. Knowledge-based engineering (KBE) systems can then be employed to integrate the formalised technical product knowledge with the order fulfilment process and thus to promote gains from knowledge reuse and sharing (Stokes, 2001). 
In literature, several attempts to increase organisational capabilities within the construction sector through IT system support can be observed, for example: Udeaja et al. (2008), Rezgui (2001) and Nitithamyong and Skibniewski (2004). In an ATO situation so-called product configuration systems are used to streamline the sales and quotation process of customised goods in satisfying the term $C A s=\min (\{F R s\}$ (Salvador and Forza, 2004). For ETO sectors such systems are moreover helpful to partly automate some of the subsequent engineering activities in assistance of $F R s=[A]\{D P s\}$ (Hvam et al., 2008). However, comparable achievements in coordinating the specification process in construction have not yet been reported.

In level 2 standardisation engineers may define a standard set of building modules or subsystem variants, like different types of facades, which can be commonly used within the precast families. The various modules and sub-systems would be reconfigured for each building project through a configure-to-order $\left(\mathrm{CTO}_{\mathrm{ED}}\right)$ approach. At level 3 standardisation finally refers to the development of entire standardised buildings or building systems, as e.g. a pre-defined set of walls to an entire house type. Since all product specifications for a building project are defined prior to the actual customer order, this strategy can be characterised as engineer-to-stock $\left(\mathrm{ETS}_{\mathrm{ED}}\right)$. Companies offering houses from a type house catalogue are a good example for an ETS $_{\mathrm{ED}}$ strategy. The focus of using product platforms for mass customizing buildings lies between the continuum of $\mathrm{ETO}_{\mathrm{ED}}$ and $\mathrm{ETS} \mathrm{SD}_{\mathrm{ED}}$, where the precast manufacturer accepts a certain level of product adjustments on a module or part level in the design based on individual customer needs. Empirical examples within related industries, such as for mass customized timber houses, can for example be found in the Japanese housing market as discussed by Gann (1996).

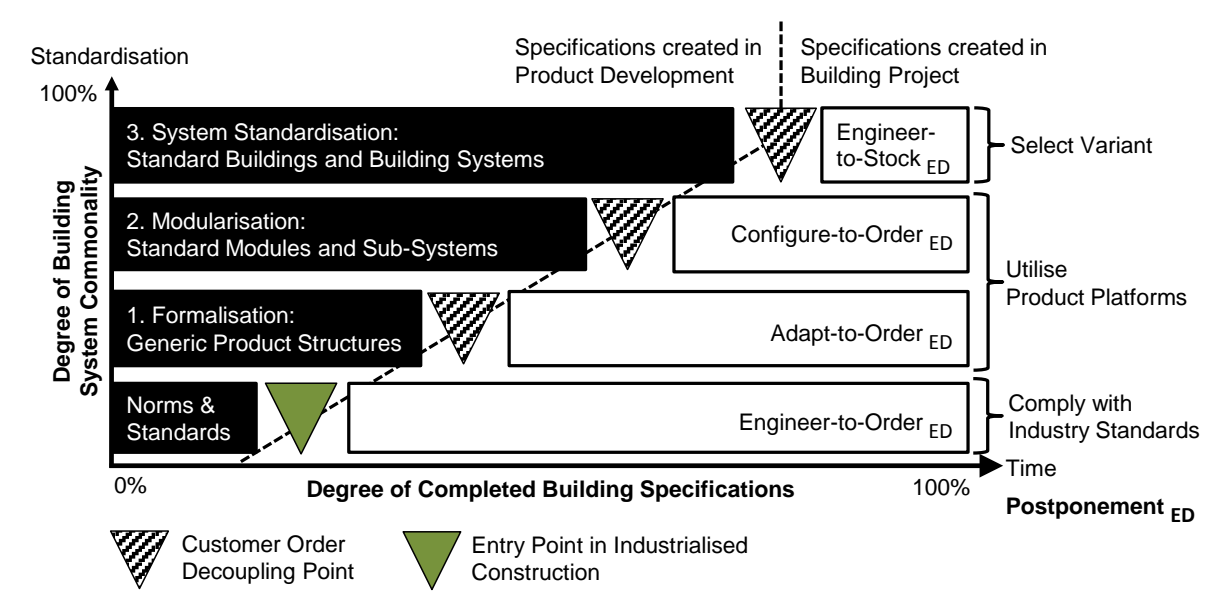

Figure 3: Leveraging the platform strategy through different decoupling points in engineering (adapted from Hvam et al., 2008)

\section{Combined platform effects on the precast value chain}

As argued by Wikner and Rudberg (2005), several feasible interrelations of a combined engineeringproduction CODP-mix can be defined. Figure 3 illustrates how two-dimensional placement of the CODP can be applied to the building industry. Precast firms are traditionally utilising a craft production approach in form of $\mathrm{ETO}_{\mathrm{ED}}$ combined with a make-to-order in the production dimension strategy $\left(\mathrm{MTO}_{\mathrm{PD}}\right)$, or in short a $\left[\mathrm{ETO}_{\mathrm{ED}}, \mathrm{MTO}_{\mathrm{PD}}\right]$ strategy. In contrast, the $\mathrm{ETS}_{\mathrm{ED}}$ strategy of type house providers is used in combination with the MTO production dimension as $\left[\mathrm{ETS}_{\mathrm{ED}}, \mathrm{MTO}_{\mathrm{PD}}\right]$. Even through for type houses all building specifications are already defined in the product development phase, the production of walls for example, would not start unless an order has been placed. According to the CODP definition, mass produced buildings with a [ETS $\mathrm{ED}_{\mathrm{ED}}, \mathrm{MTS}_{\mathrm{PD}}$ ] strategy would be created entirely based on forecasts, in other words they would be pushed to the market without any consideration from customers or clients. As displayed in Figure 4, the mass customization area covers the remaining mix of feasible engineering and production mix approaches. The Japanese timber house market can be used as an analogy for the empirical evidence of the proposed strategies. Sekisui House, for example, follows a so-called "tailored standardisation" approach with an ATO $_{\mathrm{ED}}$, $\left.\mathrm{MTO}_{\mathrm{PD}}\right]$ strategy. The company uses standard components which are mainly produced on demand and adopted to customer requirements. The on-site assembly is done by specially trained subcontractors (Gann, 1996). Another mass customization example in construction is represented by Sekisui Heim 
(Barlow et al., 2003). The company makes use of a "standardised customisation" strategy through an $\left[\mathrm{CTO}_{\mathrm{ED}}, \mathrm{MTO}_{\mathrm{PD}}\right]$ approach, where standard modular steel- and timber-frames around rooms are created off-site only few days before delivery. The modules are then directly shipped to the building sites for further assembly. An example for a $\left[\mathrm{CTO}_{\mathrm{ED}}, \mathrm{ATO}_{\mathrm{PD}}\right]$ strategy can be found on Toyota Homes. The company utilises a so-called "segmented standardisation" approach, which is comparable to Toyota's car production. Modular units are produced based on forecasts without any significant input from customers. Customisation is then performed in the on-site assembly process, where modules are recombined and adjusted to particular housing needs. All three approaches make use of process and logistics platforms to significantly reduce the time and resources for manufacturing and on-site assembly. According to Gann (1996), having modules requires 50\% less labour cost for the onsite assembly process. At the same time up to $55 \%$ assembly lead time compared to traditional prefabricated panel houses or up to 67\% compared to a carpenter-built building are being saved. Therefore, the companies are able to combine a high degree of tailoring from their customers and clients with a stable delivery quality. To achieve the required productivity, the individual postponement strategies are further supported by innovative off-site manufacturing practices, which are comparable to assembly lines car manufacturers.

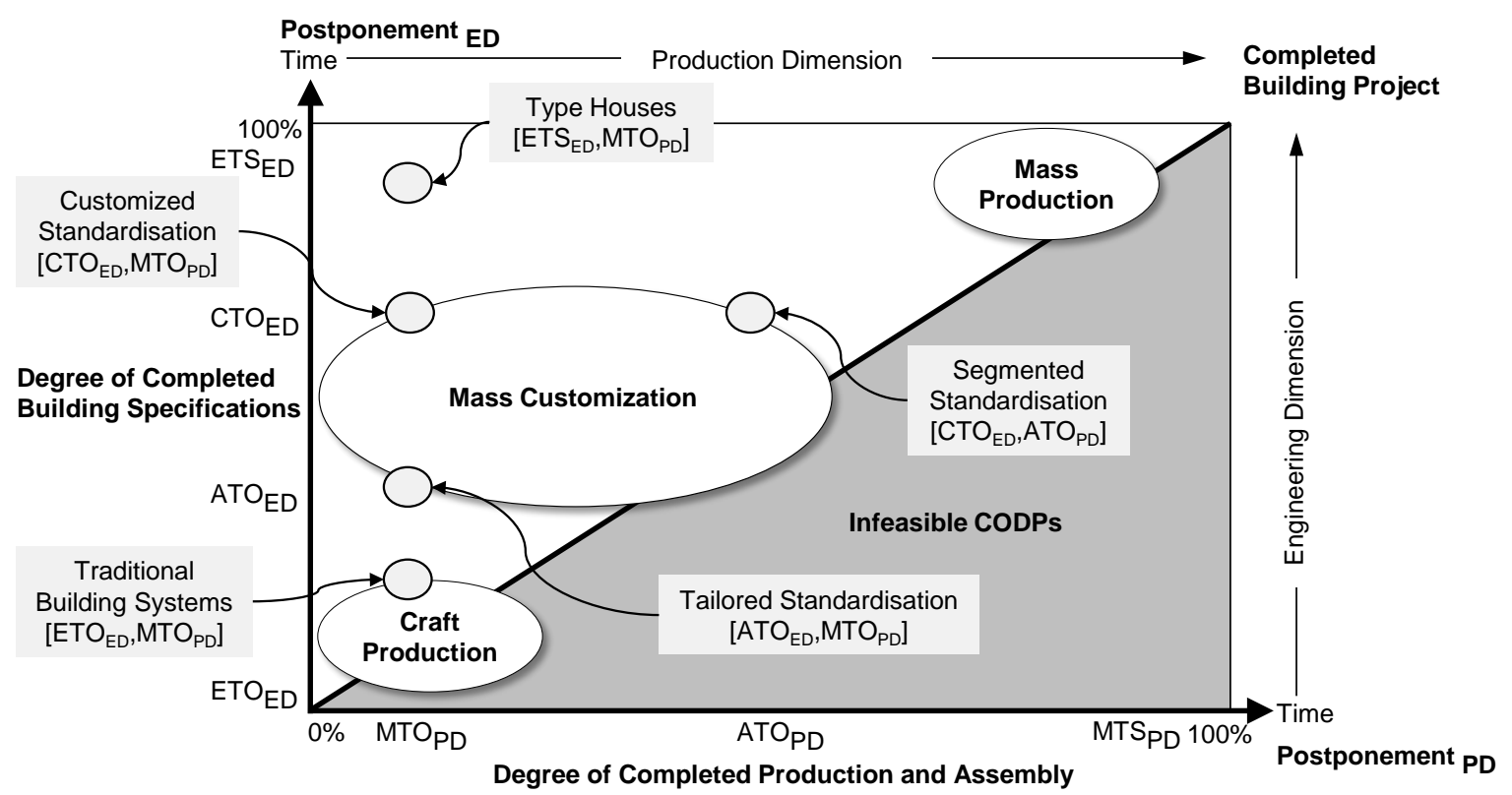

Figure 4: Leveraging the platform strategy through a two-dimensional placement of decoupling points (adapted from Rudberg and Wilkner, 2004)

\section{Research Methodology}

Despite the potential advantages of the derived platform approach, its embracement in industry has been limited (Barlow et al., 2003). This may be explained by the lack of empirical evidence and detailed explanations on how are platforms being developed and implemented through the value chain and what operational and monetary effects can thereby be observed. Acting upon this hypothesis, this paper uses a case study approach on a precast concrete manufacturer to better understand the complete phenomenon in its natural settings and to answer the question of why, what and how platforms are being developed and implemented in the precast industry (Benbasat, Goldstein, \& Mead, 1987), as a representative example of the industrial building sector. This in-depth investigation requires a longitudinal research approach, often conducted in a single case to increase the opportunity of achieving meaningful observations (Voss, Tsikriktsis, \& Frohlich, 2002). The case company was selected based on two criteria; (1) its current financial performance and market share, and (2) its ability to develop and implement a platform strategy, which is independent and thus more stable from any particular building project. The company represents a consortium of two separate organizations an architecture firm and a major precast concrete manufacturer - offering precast sandwich elements and foundations mainly for the Danish market. This joint venture was established with the purpose of 
developing the engineering, production, and assembly of pre-fabricated high performance concrete (HPC) elements, allowing the innovation process to be studied in real time.

The unit of analysis was set on four product families, consisting of one traditional precast family and three HPC families, each following a distinct platform strategy. As literature within construction remains vague on this topic, quantitative analysis methods were supplemented with qualitative research in form of interviews. The purpose of the interviews was to gather additional empirical insight into the applicability and impact of platform-based product design of precast elements. In total 45 supporting research interviews with 35 interviewees were conducted between 2011 and 2013 at the case company, its stakeholders and collaborating industry experts. A particular focus was laid on the practical implementation of the platform framework, including the discussed modelling methods for platform design. Each interview was semi-structured, to allow the flexibility of gathering additional insight throughout the interview process (Yin, 2009). The variety of professions, such as project management, structural engineering or marketing, enabled a more consistent coverage of the entire value chain. The results gained from the interviews served as a starting point for the subsequent analysis of the platform approach as well as a feedback mechanism for the development progress. In addition to that, the researchers were given access to all product family specification data, such as project offers, production drawings, and cost figures within the stated time period of two years. The realised impact of the platform use for the HPC product family was compared to the use of traditional concrete elements that are produced by precast manufacturer, where data from 45 projects performed in 2012 of traditional concrete elements and 6 projects from 2011 to 2013 with HPC products was investigated. The inspected data was triangulated against the interviews, where in a second round mismatches were addressed.

\section{Analysis and Results}

\section{Formulating the high performance concrete portfolio}

The development of the HPC product portfolio was initiated in 2010. Working on new concrete recipes, the organisation intuitively realised that many of the building challenges in developed and developing markets could potentially be addressed by using HPC as an alternative to e.g. the traditional concrete, plaster or wood materials already existing on the market. The company made an initial investigation on a number of markets both in Northern Europe as well as in developing markets in the southern part of Africa from a customer perspective. A series of CAs where formally listed, grouped and graded. A five scale approach as defined by Martin and Ishii (2002) with 1) least important and 5) very important was used to derive general requirements from the CAs into concrete DPs. Moreover, the CAs' potential for propagation of changes within the system was graded based on the stakeholders' subjective preferences (Clarkson et al. 2004). From the initial grouping of the requirements, three different distinct product families could be formed: a High-End, a Re-Insulation and a Low-End building system (Figure 5).
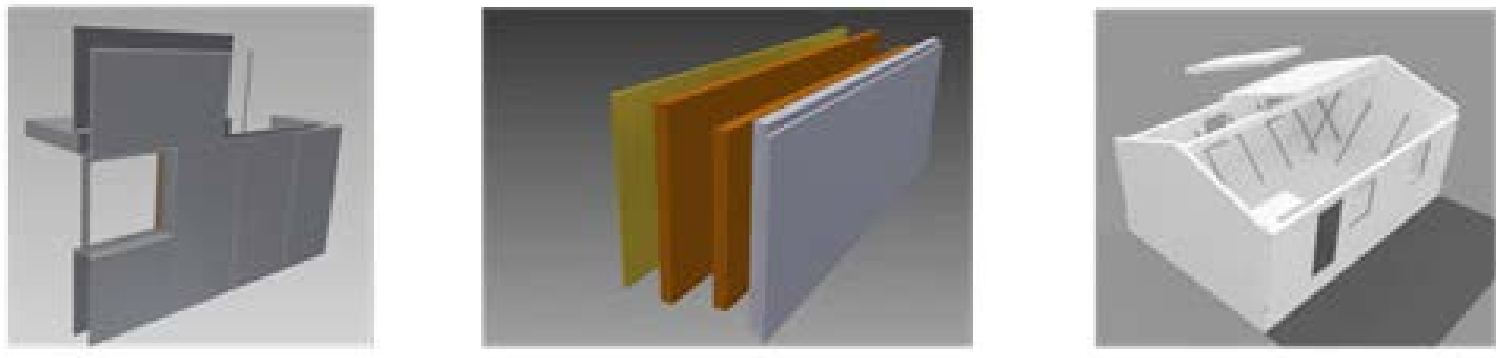

Figure 5: High performance concrete product portfolio: Re-Insulation, High-End and Low-End system

Figure 6 displays the high-level list of CAs, the characteristic value proposition for each product family where the product family names indicate the intended market application. The design of the HPC High-End solution is closer positioned to the traditional elements. It targets the high-end market segment for customers who are concerned with buildings that obtain a unique surface design and aesthetics, better insulation, increased space optimisation as well as reduced CO2 emission. The Re- 
Insulation system aims at competing with established products using metal or wood for re-insulating existing buildings. It utilises the same HPC material for offering Re-Insulation panels that, compared to existing solutions, have a longer life-time, an improved surface design and variety and low operation cost, which are easy and cheap to assemble. The third building system targets the low-end market segment of shack dwellers, which are predominately to be found in developing markets. Based on the same HPC technology, this solution provides stable and long-lasting buildings with a reasonable quality at a competitive price and thus suggests a fundamental alternative to existing lowend housing today. Due to the special requirements for this market segment (Ofori, 2007), the LowEnd system is emphasising a strong focus on using local and often unskilled labour, cheap and simple production with predominantly local material and a simple and quick on-site assembly. This explicit value proposition allowed the engineers to focus on aspects within each building system which generate a direct value to the customer, while limiting the non-value adding activities.

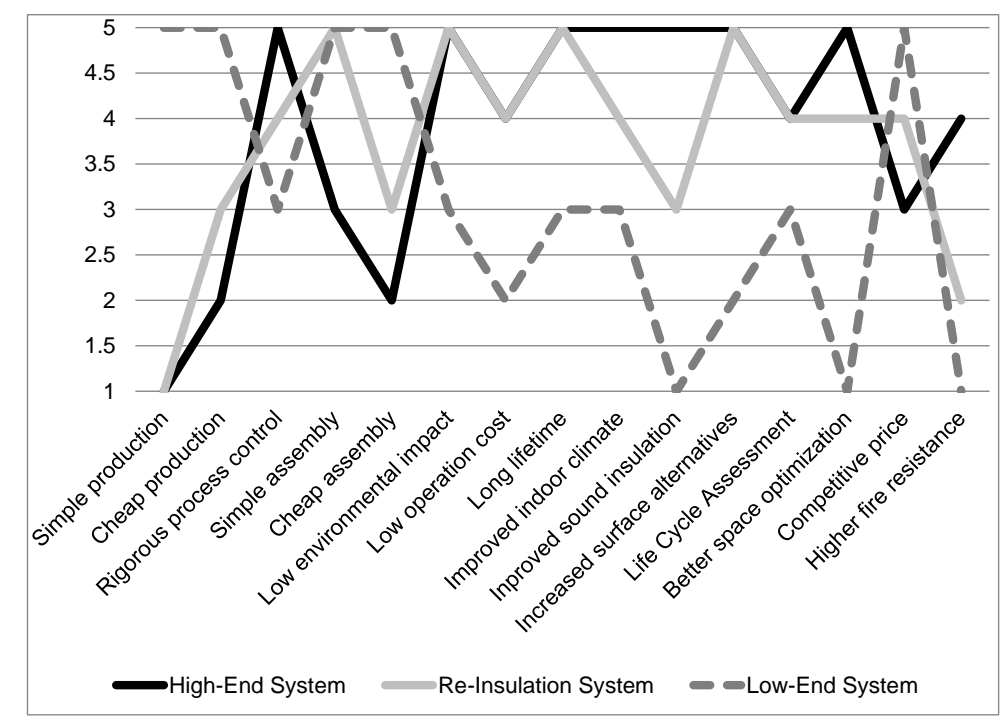

Figure 6: Value proposition of the three product families with evaluated customer attributes

With the initial value definition for each product family, the design of the building systems was created in a close collaboration between architects and engineers. To compare the similarities and differences between the families, the traditional precast products are used as threshold values representing the current market norms for the industry. The result of the comparison is summarised in Table 1, where for each product family the heuristic approach to platforms has been applied. The different views of the building system where modelled according to the generic modelling methods introduced by Hvam et al. (2008), while intra-domain matrixes where used to connect views.

\section{The product platforms used in the high-performance concrete portfolio}

The High-End HPC system consists of sandwich elements and their connection to each other and to other building systems, such as to foundation or ceiling. From an engineering perspective, the modified concrete recipe of the elements obtains a number of functional advantages compared to the traditional concrete elements, which facilitate fulfilling the objective of $C A s=\min (\{F R s\})$. In addition to an altered concrete material, a longer building lifetime has been obtained through a new joining system made from stainless steel. From a part view, with the High-End system the company focused on the value adding variety on the component level, while preserving the flexibility to meet all customer demands within the target market segment. Compared to traditional concrete elements, the High-End system uses fewer variants for reinforcing, insulating and connecting the sandwich elements, resulting in an overall higher part commonality of the system.

The Re-Insulating system utilises the same HPC material as the High-End solution. To conform to the requirements (FRs) of the re-insulating market, several additional DPs have been added. Instead of having a back plate made from concrete, a second layer of insulation material has been attached to the elements. A new mounting system ensures the fixation of the elements to the existing building, while a simpler jointing solution made out of stainless steel has been developed to seal the surface of the system. The Re-Insulation elements consist of a limited number of modules coming in different sizes. To ensure a high degree of flexibility, all modules use the same mounting and jointing system 
and can be combined and exchanged without affecting each other. Since the HPC material is more costly compared to the competitive products on the market made out of wood or metal, to reduce the cost of the each element, unnecessary variety of the remaining parts has been lowered considerably. However, compared to the existing market standards, the additional variety of surfaces ensures the high aesthetic value of the overall re-insulation. For the Low-End system on the other hand flexibility is less important than price. As all HPC building systems mainly share the same raw materials, the company must focus on standardising the Low-End system as much as possible. It uses two different element types, roofs and surfaces in combination with common components to create entire buildings at a competitive price. The shape and size of the buildings can be modified, as elements can be moved, recombined or additional ones can be attached.

Table 1: Overview of the platform strategy of the high performance concrete portfolio in relation to traditional precast elements

\begin{tabular}{|c|c|c|c|c|}
\hline Dimension & Traditional Precast & High-End System & Re-Insulation System & Low-End System \\
\hline Product Portfolio & $\begin{array}{l}\text { Market average requirements } \\
\text { for aesthetic, insulation, } \\
\text { space optimisation, lifetime } \\
\text { and environment }\end{array}$ & $\begin{array}{l}\text { High requirements for aesthetic, } \\
\text { insulation, space optimisation, } \\
\text { lifetime, quality and environment; } \\
\text { low requirements on price, easy } \\
\text { production and assembly }\end{array}$ & $\begin{array}{l}\text { High requirements for insulation, } \\
\text { lifetime and assembly and space } \\
\text { optimisation; moderate } \\
\text { requirements for aesthetic and } \\
\text { price }\end{array}$ & $\begin{array}{l}\text { High requirements for surface } \\
\text { design, easy and cheap } \\
\text { production and assembly; } \\
\text { moderate requirements on } \\
\text { lifetime and environment; low } \\
\text { requirements for aesthetic, } \\
\text { insulation and space optimisation }\end{array}$ \\
\hline \multicolumn{5}{|l|}{ Product Platform } \\
\hline Engineering View & $\begin{array}{l}\text { Traditional concrete recipe, } \\
\text { market norms for strength, } \\
\text { load-bearing capacity, heat } \\
\text { and sound insulation, lifting }\end{array}$ & $\begin{array}{l}\text { High performance concrete, } \\
\text { increased capabilities in strength, } \\
\text { load-bearing capacity, lifetime, } \\
\text { heat and sound insulation, } \\
\text { reduced CO2 emission; } \\
\text { redesigned joining system }\end{array}$ & $\begin{array}{l}\text { High performance concrete with } \\
\text { the same characteristics as the } \\
\text { high-end system; redesigned } \\
\text { insulation, joining and mounting } \\
\text { system }\end{array}$ & $\begin{array}{l}\text { High performance concrete with } \\
\text { the same characteristics as the } \\
\text { high-end system; redesigned } \\
\text { joining and mounting system to } \\
\text { other buildings }\end{array}$ \\
\hline Part View & $\begin{array}{l}\text { Part commonality at market } \\
\text { norms; iron mesh with } \\
\text { limited variety, multiple shear } \\
\text { connectors, insulation } \\
\text { materials, reinforcement, } \\
\text { recesses, concrete recipes } \\
\text { and surfaces }\end{array}$ & $\begin{array}{l}\text { Increased commonality in element } \\
\text { dimensions, common iron mesh, } \\
\text { two shear connectors, two } \\
\text { insulation materials, limited } \\
\text { reinforcement, common concrete } \\
\text { recipe, alternative additional } \\
\text { surfaces and joining elements }\end{array}$ & $\begin{array}{l}\text { Few common element } \\
\text { dimensions, common fibre } \\
\text { mesh, common mounting } \\
\text { system to walls, two insulation } \\
\text { materials, common } \\
\text { reinforcement and concrete } \\
\text { recipe, few surfaces, common } \\
\text { joining elements }\end{array}$ & $\begin{array}{l}\text { Two common element } \\
\text { dimensions, common fibre } \\
\text { mesh, shear connector, } \\
\text { insulation material, } \\
\text { reinforcement, recesses, and } \\
\text { concrete recipe, two surfaces } \\
\text { and roofs, common joining } \\
\text { elements }\end{array}$ \\
\hline IT Support & $\begin{array}{l}\text { No specification process } \\
\text { support }\end{array}$ & No specification process support & No specification process support & No specification process support \\
\hline \multicolumn{5}{|l|}{ Process Platform } \\
\hline Production View & $\begin{array}{l}\text { Flexible processes, little } \\
\text { mould commonality }\end{array}$ & $\begin{array}{l}\text { Flexible processes, little mould } \\
\text { commonality }\end{array}$ & $\begin{array}{l}\text { Limited process flexibility, high } \\
\text { mould commonality }\end{array}$ & $\begin{array}{l}\text { Limited process flexibility, very } \\
\text { high mould commonality }\end{array}$ \\
\hline Team Members & Unstable relationships & Stable relationships & Stable relationships & Stable relationships \\
\hline Handover Process & $\begin{array}{l}\text { Little quality control, no } \\
\text { formal handover procedures }\end{array}$ & $\begin{array}{l}\text { Pre-defined end deliveries } \\
\text { demanding for well defined sub- } \\
\text { delivery for each handover }\end{array}$ & $\begin{array}{l}\text { Pre-defined end deliveries } \\
\text { demanding for well defined sub- } \\
\text { delivery for each handover }\end{array}$ & $\begin{array}{l}\text { Pre-defined end deliveries with } \\
\text { less strict sub-delivery }\end{array}$ \\
\hline IT Support & $\begin{array}{l}\text { Inconsistent data collection, } \\
\text { no systematic learning }\end{array}$ & $\begin{array}{l}\text { Centralised documentation, i.e. } \\
\text { measurements, observations, } \\
\text { sensors, tagging, quality control, } \\
\text { central database }\end{array}$ & $\begin{array}{l}\text { Centralised documentation, i.e. } \\
\text { measurements, observations, } \\
\text { sensors, tagging, quality control, } \\
\text { central database }\end{array}$ & $\begin{array}{l}\text { Centralised documentation, } \\
\text { optional quality control }\end{array}$ \\
\hline Continuous Improvement & Long-term cycles & Short-term cycles & Short-term cycles & Mid-term cycles \\
\hline
\end{tabular}

\begin{tabular}{|c|c|c|c|c|}
\hline \multicolumn{5}{|l|}{ Logistics Platform } \\
\hline Transportation & $\begin{array}{l}\text { Little space utilisation due to } \\
\text { weight restrictions for trucks }\end{array}$ & $\begin{array}{l}\text { High space utilisation due to } 50 \% \\
\text { less volume and } 70 \% \text { less weight }\end{array}$ & $\begin{array}{l}\text { High space utilisation, } \\
\text { comparable to re-insulation } \\
\text { market norms }\end{array}$ & $\begin{array}{l}\text { Maximum space utilisation with } \\
\text { smaller trucks, due to } 80-95 \% \\
\text { less volume and weight }\end{array}$ \\
\hline Assembly View & $\begin{array}{l}\text { Crane size and assembly } \\
\text { process according to market } \\
\text { norms }\end{array}$ & $\begin{array}{l}\text { Smaller cranes due to reduced } \\
\text { element weight, higher } \\
\text { requirements during assembly } \\
\text { process }\end{array}$ & $\begin{array}{l}\text { Smaller cranes due to reduced } \\
\text { element weight, fast assembly } \\
\text { process with standardized } \\
\text { tooling, no scaffolds }\end{array}$ & $\begin{array}{l}\text { Small cranes, more than } 50 \% \\
\text { less assembly time with } \\
\text { standardized tooling }\end{array}$ \\
\hline Team Members & Unstable relationships & Stable relationships & Stable relationships & Stable relationships \\
\hline Handover Process & $\begin{array}{l}\text { Little quality control, no } \\
\text { formal handover procedures }\end{array}$ & $\begin{array}{l}\text { Pre-defined end deliveries } \\
\text { demanding for well defined sub- } \\
\text { delivery for each handover }\end{array}$ & $\begin{array}{l}\text { Pre-defined end deliveries } \\
\text { demanding for well defined sub- } \\
\text { delivery for each handover }\end{array}$ & $\begin{array}{l}\text { Pre-defined end deliveries with } \\
\text { less strict sub-delivery }\end{array}$ \\
\hline Continuous Improvement & Long-term cycles & Short-term cycles & Short-term cycles & Mid-term cycles \\
\hline Postponement Strategy & ETOED, MTOPD & ATOED, MTOPD & СТOळ, MTOPD & CTOED, MTOPD \\
\hline
\end{tabular}

\section{The process platforms used in the high-performance concrete portfolio}

In construction terms the HPC product platforms exhibit a rather radical degree of redesign compared to the traditional concrete elements. From a production perspective this difference is less obvious, as all three HPC building systems mainly go through the same production steps as the traditional elements. Yet, a cost and time advantage is achieved through reusing already existing production facilities, machineries, equipment and labour. Additional benefits arise with the higher degree of part 
and module commonality of the HPC portfolio, resulting in less flexible but at the same time more reliable and stable production steps. While for the High-End solution the effect from increased part commonality is smaller, the Re-Insulation and Low-End elements strongly benefit from the standardisation attempts on the module level. Through the limited variety in dimensions, the company reuses a set of standardised moulds for casting and recesses made out of steel, thereby reducing waste and the need for resetting the production. Furthermore, the thinner dimensions and sharper edges of the HPC elements result in smaller production tolerances. To meet the increased quality demands when working with HPC material, stable and well trained teams have been created along with welldefined handover procedures for process deliveries. The high quality standards are ensured with additional IT support for measuring, monitoring and tracking the entire production. A central data base has been installed to collect and evaluate the acquired information. This constant quality control has led to shorter continuous improvement cycles of the HPC products and the way how they are produced.

\section{The logistics platforms used in the high-performance concrete portfolio}

A major advantage of using HPC instead of traditional concrete recipes is the reduced dimensions and weight of the elements. Transportation costs of the elements are typically responsible for $10 \%$ of the cost of the entire building system. Therefore reducing the costs of shipping the elements can have a big impact on the overall profitability of the building projects. This effect is exemplified on the HighEnd system. Here, the HPC sandwich elements have 50\% less volume and up 70\% less weight compared to traditional precast elements. In result the company is able to better utilise the space of the trucks that are used for shipping and have considerable savings during assembly, which would otherwise be restricted by the weight of the elements. In developing markets the reduced volume and weight of the Low-End building system even accounts for 80-95\%. Smaller and lighter elements in turn make it possible to transport the elements with smaller trucks even through rural and unpaved areas. Another factor contributing to a lower price is that fewer variants of the product are offered based on the Low-End product platform. From an assembly perspective the volume and weight reduction of the HPC portfolio means that the company can operate with smaller and cheaper cranes at the building site. Moreover, with the Re-Insulation and Low-End solution, the case company has introduced a new fast and simple assembly process, where standardised tooling is utilised for the entire on-site work. Apart from the benefits coming from smaller and lighter elements and standardised processes, a strong emphasis is being set on the employees and the quality of delivery. Comparable with the process platforms, stable and specialised teams are making sure that the predefined deliveries and all handover processes are being kept. Besides, the increased transparency during assembly leads to shorter feedback cycles; allowing the company to continuously improve their procedures in shorter terms.

\section{Platform effects in the high-performance portfolio}

The platform analysis of the HPC portfolio demonstrates the potential advantage of focussing on the right balance between commonality and distinctiveness within each view of a product family. For the case company an increased reuse of building specifications, machineries, tools and processes created in the development phase resulted in a higher degree of commonality along the value chain of a building project. Compared to a traditional precast project, an increased reuse capitalises in the ability to delay the differentiating activities of each project. Figure 7 depicts the postponement strategy of the three HPC product families. Depending on the intended positioning in the market, each product family is using the platforms to a degree, which allows placing the two-dimensional CODP according to the optimum cost-value relation. A traditional building project at the case company today requires in average three hours of engineering work per concrete element, once the detailed design of a building has been finalised. Having invested in formalising its offerings to the market, the High-End system on the other hand adapts systematically the building specification created during product development to the individual requirements of a project with an $\left[\mathrm{ATO}_{\mathrm{ED}}, \mathrm{MTO}_{\mathrm{PD}}\right]$ strategy. The firm operates with the $\mathrm{ATO}_{\mathrm{ED}}$ strategy within the boundaries of the assigned solution space in engineering, allowing for a higher level of flexibility in the subsequent production and assembly. While ensuring the desired delivery quality, the company strives in gaining economies of time throughout the specification process of the building, saving up to $20 \%$ of engineering time for completing the building specifications. The effect of increased reuse of building specifications is even stronger for the Re- 
Insulation and the Low-End system, where up to $80 \%$ of the overall engineering time is being economised. Both systems utilise a $\left[\mathrm{CTO}_{\mathrm{ED}}, \mathrm{MTO}_{\mathrm{PD}}\right]$ approach, in which the benefits of having standardised modules take effect already at the conceptual design phase of the project. Even though formal product architectures have been established, at the time of the study the case company has not invested in establishing a configuration system for any of their products. With the planned implementation of IT, additional positive lead time effects in engineering are expected. However, the observations indicate that the successful use of a configuration system support depends on how well the organizational changes are being implemented, rather than if such a system is capable of assisting the specification process.

The higher level of commonality along the entire life cycle of the building project directs to additional reductions of lead times within production and on-site assembly. The additional benefits from using the platforms can be exemplified on the Low-End system, where the standardised production processes report a 30-50\% lead time reduction. The redefined on-site assembly allows the company to use standardised tooling combined with lighter and smaller elements to assemble a single family building with three workers and one single tool in merely seven hours after having cast the foundation. With the ability to deliver quick and cheap housing, the company aims at directly addressing the growing housing demand in developing regions. As indicated in Figure 7, once access to new markets has been gained, scale-up programs are planned to increase the productivity of factories. By moving from a $\left[\mathrm{CTO}_{\mathrm{ED}}, \mathrm{MTO}_{\mathrm{PD}}\right]$ towards an IKEA model $\left[\mathrm{CTO}_{\mathrm{ED}}, \mathrm{ATO}_{\mathrm{PD}}\right]$ strategy $(\mathrm{H}$. $\mathrm{Li}$ et al., 2011), the different wall elements can then be produced based on a forecast, reducing the delivery time of the building to the lead time of transportation and assembly. While staying within the boundaries of the building system, each customer is then able to order his configured house, based on an individual combination of the elements.

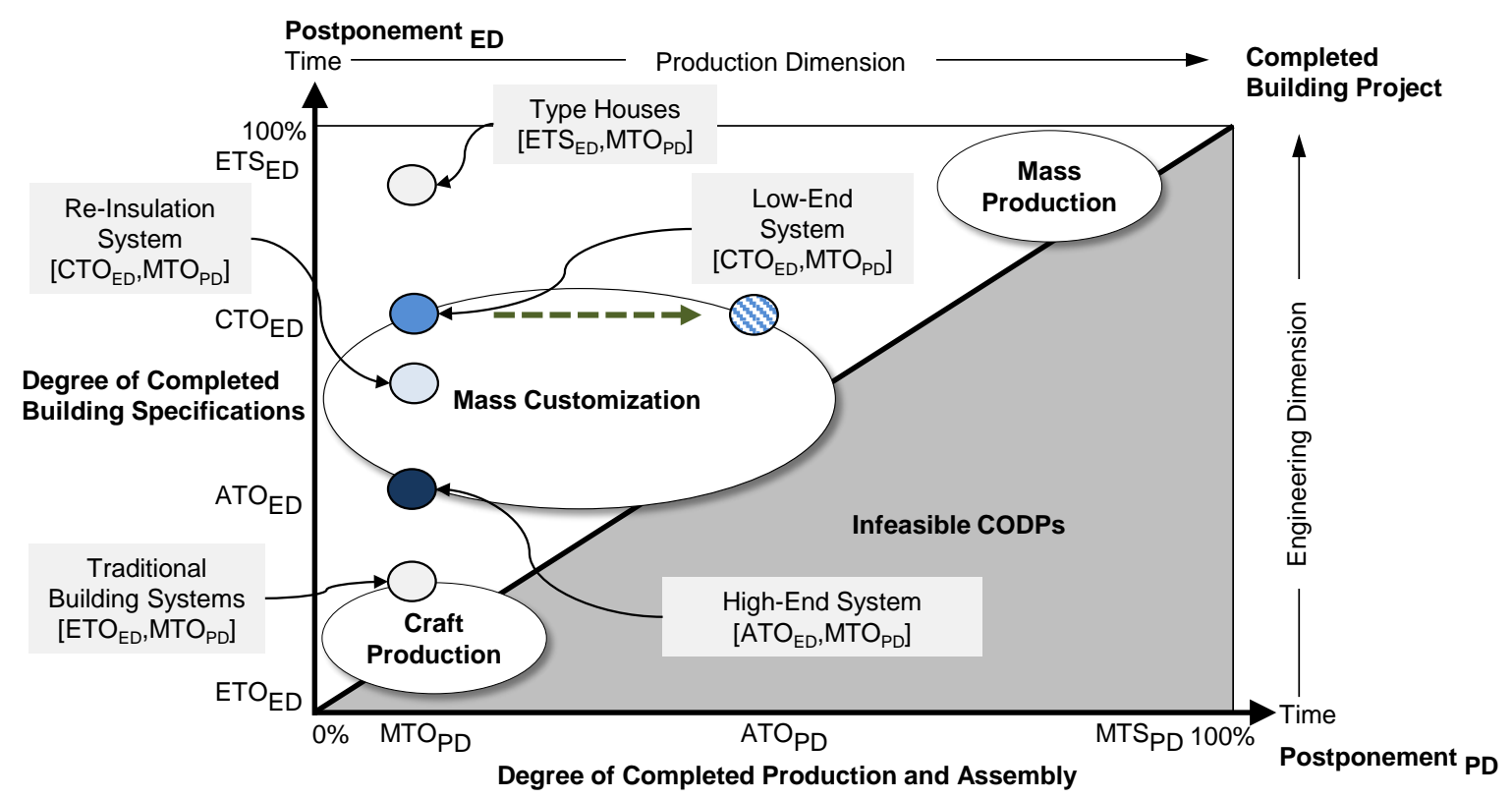

Figure 7: Platform leverage strategies for the HPC portfolio

Apart from economies of time, with the platform strategies the company is bridging the paradigm of delivering the optimum cost-value relation for each HPC product family. Figure 8 illustrates the impact the utilised platforms have on the accumulated cost of the case company throughout a building project. While the higher flexibility of the High-End system results in a relatively high cost structure which is close to the traditional building systems, it focuses on generating higher margins through a selective value proposition. An increase in material costs is compensated with savings in engineering, transportation and assembly, while the improved aesthetics and material properties add additional value to customers. Similar to the platform strategy of car manufacturers (Proff, 2000), as discussed previously the Re-Insulation and Low-End systems benefit from adapting product innovation, production technologies as well as better utilised resources during transportation and assembly of the High-End system to constantly improve their platforms. Furthermore, being more concerned with 
offering competitive prices, the two families focus on reusing their assets along building projects, where non-value adding variety is reduced to a minimum. This enforced simplicity for example lowers the cost of a Low-End building to price points that are compatible to slack dwellers in development markets, yet using comparable materials and product quality as the High-End system. Finally, the overall platform strategy of the company has resulted in a number of patterns, which are used to secure their competitive advantage from the illustrated product and production innovations.

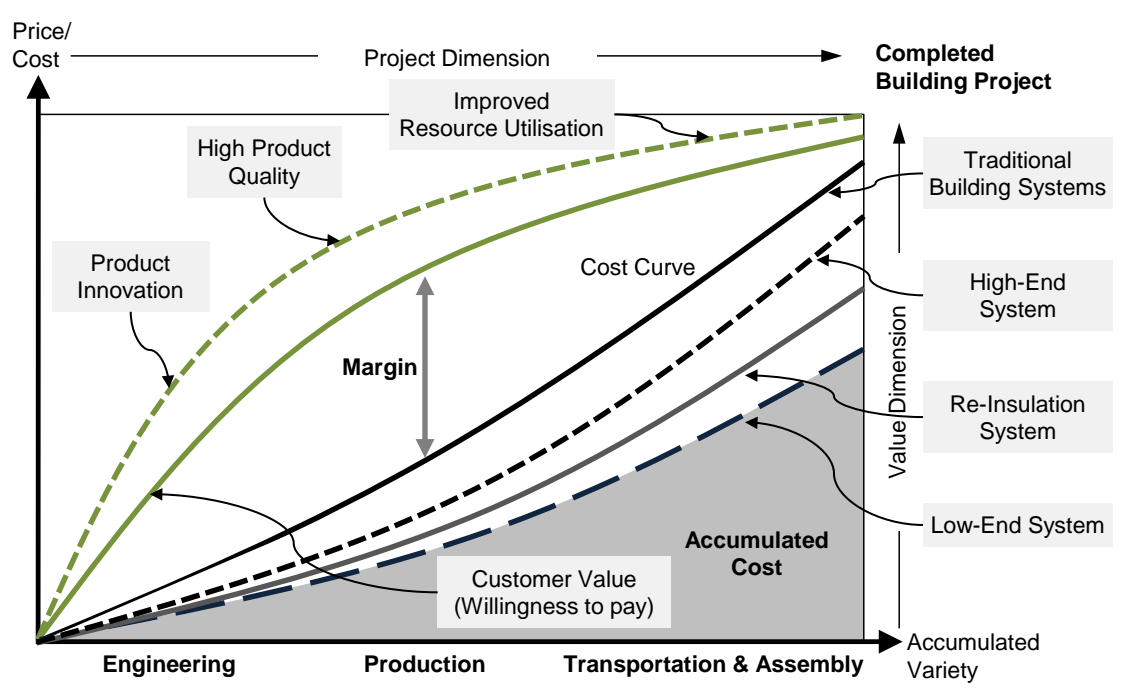

Figure 8: Economic implication of the HPC platforms in the case company

\section{Conclusion}

Research in construction has long been focusing on adapting concepts and methods from other industries such as the automotive industry to bring forward industrialisation and to reach higher productivity levels. While the accommodation of lean principles has received much attention, fundamental methods for ensuring an efficient customisation of buildings have mainly been neglected. Mass customisation aims at bridging this gap of delivering customised products at near mass production efficiency. Successful mass customizers to be found in industry apply platforms as a means to acquire economies of scale while maintaining adjustable product structures, flexible processes and adaptive organisations. In addition they use product configuration systems around their platforms in support of their specification processes. Scholars approaching this topic have to adapt the two principles to the ETO situation in construction and to present practical guidelines for their implementation.

In addressing the two issues, this paper has presented a holistic view of platforms as a framework for understanding how mass customizing building projects is being facilitated in general. The study uses the precast sector as a representative industry to formalise the value chain of a building project in relation to the different manufacturing strategies according to the CODP. By drawing upon theory in platform development, the application of a product, process and logistics platform has been explained on the example of a building project. To create the right balance between commonality and distinctiveness, relationships between the platform domains as well as the connection to market requirements have been expressed through generic and matrix-based modelling methods. Then, the two-dimensional postponement of the CODP has been employed to synthesise the relevance of using configuration systems and to conceptualise the operational effects of platforms throughout the lifetime of a building project. Likewise, a cost-value concept has been introduced to explain the related economic implications.

The paper employs a mixed-method research design, from both qualitative and quantitative sources, to collect evidence for the holistic view on platforms within the precast sector and to validate the developed framework. The applied methodology facilitated the in-depth exploration of how practitioners from the industry take up the platform concept, what challenges they face, as well as what benefits they realise. In the subsequent analysis, three distinct platform strategies from a precast manufacturer were compared to the otherwise traditional building projects. Each strategy was related 
to the previously introduced framework and discussed according to both its operational as well as economic implications. The obtained results demonstrated strong incentives for implementing several feasible platform constructs within the precast industry. Moreover, the benefits from integrating configuration systems throughout the specification process of buildings were conceptually elaborated, for which an enormous potential for future research has been recognized. Pragmatically, the findings suggest that utilising platforms does not necessarily imply sacrificing design flexibility and customer value respectively in favour of efficiency, but rather involves the creation of an optimum cost-value relation for the target market segment. This case study approach admittedly implies certain limitations with respect to generalisability and repeatability of the research. The increasing maturity level of the industry entails that essentially any major precast manufacturer operating in developed markets obtains few universal capabilities with respect to its value chain (Z. Li, Shen, \& Xue, 2014), and may hence be used as a basic representative example to test the introduced framework. On the other hand, as demonstrated a consistent platform approach requires a certain level of development effort to obtain the discussed two-dimensional postponed strategy. This innovation process has to be performed independently from any particular building project and involves the application of the discussed modelling methods (Brière-Côté et al., 2010; Meyer \& Lehnerd, 1997; Suh, 2001), which is however traditionally rarely the case within the building sector (Gambatese \& Hallowell, 2011). Consequently, further empirically-grounded research on a variety of building systems is needed to better understand the complementary effects of platform modelling, configuration system support and postponement, as a result of the introduced framework. This would increase the interest in mass customization within house building and may further lead to a wider acceptance of the presented methods.

\section{References}

Baldwin, C. Y., and Clark, K. B. (2000), Design rules, volume 1: The power of modularity, MIT Press, Cambridge (Mass.)

Barlow, J., Childerhouse, P., Gann, D., Hong-Minh, S., Naim, M. and Ozaki, R. (2003), “Choice and delivery in housebuilding: lessons from Japan for UK housebuilders”, Building Research and Information, Vol. 31 No. 2, pp. 134-145.

Benbasat, I., Goldstein, D. K., Mead, M. (1987), “The Case Research Strategy in Studies of Information Systems”, MIS Quarterly, Vol. 11, pp. 369-396.

Blismas, N., Pasquire, C. and Gibb, A. (2006), "Benefit evaluation for off-site production in construction”, Construction Management and Economics, Vol. 24 No. 2, pp. 121-130.

Bertrand, J.W.M. and Mu, D.R. (1993), “Production control in engineer-to-order firms”, International Journal of Production Economics, Vol. 31, pp. 3-22.

Brière-Côté, A., Rivest, L. and Desrochers, A. (2010), “Adaptive generic product structure modelling for design reuse in engineer-to-order products”, Computers in Industry, Vol. 61 No. 1, pp. 53-65.

Chen, Y., Okudan, G.E. and Riley, D.R. (2010), "Sustainable performance criteria for construction method selection in concrete buildings”, Automation in Construction, Vol. 19 No. 2, pp. 235244.

Clarkson P. J., Simons C., and Eckert C. (2004), “Predicting change propagation in complex design”, ASME Journal of Mechanical Design, Vol. 126 No. 5, pp. 788-797.

Do, N., Choi, I. J., and Jang, M. K. (2002), “A structure-oriented product data representation of engineering changes for supporting integrity constraints”, International Journal of Advanced Manufacturing Technology, Vol. 20 No. 8, pp. 564-570. 
Du, X., Jiao, J. and Tseng, M.M. (2001), “Architecture of Product Family: Fundamentals and Methodology”, Concurrent Engineering, Vol. 9 No. 4, pp. 309-325.

Eppinger, S. D., Whitney, D. E., Smith, R. P., and Gebala, D. A. (1994), “A model-based method for organizing tasks in product development”, Research in Engineering Design, Vol. 6 No 1, pp. 113.

Felfernig, A., Friedrich, G.E., and Jannach, D. (2000), "UML as domain specific language for the construction of knowledge-based configuration systems”, International Journal of Software Engineering and Knowledge Engineering, Vol. 1 No. 4, pp. 449-469.

Gambatese, J. A., Hallowell, M. (2011), "Enabling and measuring innovation in the construction industry”, Construction Management and Economics, Vol. 29, pp. 553-567.

Gann, D.M. (1996), “Construction as a manufacturing process? Similarities and differences between industrialized housing and car production in Japan”, Construction Management and Economics, Vol. 14 No. 5, pp. 437-450.

Garwood, D. (1988), Bills of material structured for excellence, R.D. Garwood, Atlanta.

Girmscheid, G. (2007), Forschungsmethodik in den Baubetriebswissenschaften, ETH, Zürich.

Haug, A., Ladeby, K., and Edwards, K. (2009), “From engineer-to-order to mass customization”, Management Research News, Vol. 32 No. 7, pp. 633-644.

Hobday, M. (2000), “The project-based organisation: an ideal form for managing complex products and systems?”, Research Policy, Vol. 29 No. 7-8, pp. 871-893.

Hvam, L., Mortensen, N. H., and Riis, J. (2008), Product customization, Springer, Berlin.

Jaillon, L. and Poon, C.S. (2009), "The evolution of prefabricated residential building systems in Hong Kong: A review of the public and the private sector", Automation in Construction, Vol. 18 No. 3, pp. 239-248.

Jansson, G., Johnsson, H. and Engström, D. (2013), "Platform use in systems building”, Construction Management and Economics, Vol. 4, pp. 1-13.

Jiao, J. and Tseng, M.M. (1999), “A methodology of developing product family architecture for mass customization”, Journal of Intelligent Manufacturing, Vol. 10 No. 1, pp. 3-20.

Jiao, J.R., Simpson, T.W. and Siddique, Z. (2007), "Product family design and platform-based product development: a state-of-the-art review”, Journal of Intelligent Manufacturing, Vol. 18 No. 1, pp. 5-29.

Kiviniemi, A. (2005), “Requirements Management Interface to Building Product Models”, Technical Report [161], Stanford University, Palo Alto, 03.2005.

Konijnendijk, P.A. (1994), “Coordinating marketing and manufacturing in ET0 companies”, International Journal of Production Economics, Vol. 37 No. 1, pp. 19-26.

Lachimpadi, S.K., Pereira, J.J., Taha, M.R. and Mokhtar, M. (2012), “Construction waste minimisation comparing conventional and precast construction (Mixed System and IBS) methods in high-rise buildings: A Malaysia case study”, Resources, Conservation and Recycling, Vol. 68, pp. 96-103. 
Li, H., Guo, H.L., Skitmore, M., Huang, T., Chan, K.Y.N. and Chan, G. (2011), “Rethinking prefabricated construction management using the VP-based IKEA model in Hong Kong”, Construction Management and Economics, Vol. 29 No. 3, pp. 233-245.

Li, Z., Shen, G., Xue, X. (2014), “Critical review of the research on the management of prefabricated construction”, Habitat International, Vol. 43, pp. 240-249.

Martin, M. V., and Ishii, K. (2002), "Design for variety: developing standardized and modularized product platform architectures”, Research in Engineering Design, Vol. 13 No. 4, pp. 213-235.

Meyer, M. H. and Lehnerd, A. P. (1997), The Power of Product Platforms, Free Press, New York.

Mesihovic S., Malmqvist J., and Pikosz P. (2004), "Product data management system-based support for engineering project management”, Journal of Engineering Design, Vol. 15 No. 4, pp. 389403.

Mora, R., Bédard, C., and Rivard, H. (2008), “A geometric modelling framework for conceptual structural design from early digital architectural models”, Advanced Engineering Informatics, Vol. 22 No. 2, pp 254-270.

Nitithamyong, P. and Skibniewski, M. J. (2004), "Web-based construction project management systems: how to make them successful?”, Automation in Construction, Vol. 13 No. 4, pp. 491506.

Ofori, G. (2007), “Construction in Developing Countries”, Construction Management and Economics, Vol. 25 No. 1, pp. 1-6.

Pan, W., Gibb, A.G.F. and Dainty, A.R.J. (2007), "Perspectives of UK housebuilders on the use of offsite modern methods of construction”, Construction Management and Economics, Vol. 25 No. 2, pp. 183-194.

Parry, G., and Graves, A. (2008), Build to order: The road to the 5-day car, Springer, London.

Pine, B. J. (1993), Mass customization: the new frontier in business competition, Harvard Business School Press, Boston.

Proff, H. (2000), "Hybrid strategies as a strategic challenge — the case of the German automotive industry”, Omega, Vol. 28 No. 5, pp. 541-553.

Rahim, A.R.A. and Baksh, M.S.N. (2003), "The need for a new product development framework for engineer-to-order products”, European Journal of Innovation Management, Vol. 6 No. 3, pp. 182-196.

Rezgui, Y. (2001), "Review of information and the state of the art of knowledge management practices in the construction industry”, The Knowledge Engineering Review, Vol. 16 No. 3, pp. 241-254.

Robertson, D. and Ulrich, K. (1998), "Planning for Product Platforms”, Sloan Management Review, Vol. 39 No. 4, pp. 19-31.

Sacks, R., Eastman, C.M. and Lee, G. (2004), "Process Model Perspectives on Management and Engineering Procedures in the Precast/ Prestressed Concrete Industry”, Journal of Construction Engineering and Management, Vol. 130 No. 2, pp. 206-215. 
Salvador, F., and Forza, C. (2004), "Configuring products to address the customization-responsiveness squeeze: A survey of management issues and opportunities", International Journal of Production Economics, Vol. 91 No. 3, pp. 273-291.

Sawhney, M.S. (1998), "Leveraged High-Variety Strategies From Portfolio Thinking : to Platform Thinking”, Journal of the Academy of Marketing Science, Vol. 26 No. 1, pp. 54-61.

Sharman, G. (1984), “The rediscovery of logistics”, Harvard Business Review, Vol. 62 No. 5, pp. 7179.

Simpson, T.W., Bobuk, A., Slingerland, L. a., Brennan, S., Logan, D. and Reichard, K. (2011), "From user requirements to commonality specifications: an integrated approach to product family design”, Research in Engineering Design, Vol. 23 No. 2, pp. 141-153.

Stevens, R. and Martin, J. (1995), “What is Requirements Management?”, Proceedings of the Fifth Annual International Symposium of the INCOSE, Vol. 2, pp. 13-18.

Stokes, M. (2001), Managing Engineering Knowledge - MOKA: Methodology for Knowledge Based Engineering, ASME Press, New York.

Steward, D. V. (1981), “The Design Structure System: A Method for Managing the Design of Complex Systems”, IEEE Transactions on Engineering Management, Vol. 28 No. 3, pp. 71-74.

Su, J. C., Chang, Y. L., and Ferguson, M. (2005), "Evaluation of postponement structures to accommodate mass customization”, Journal of Operations Management, Vol. 23 No 3-4, pp. 305-318.

Suh, N. P. (2001), Axiomatic Design: Advances and Applications, Oxford University Press, New York.

Thuesen, C. and Hvam, L. (2011), "Efficient on -site construction : learning points from a German platform for housing”, Construction Innovation: Information, Process, Management, Vol. 11 No. 3, pp. 338-355.

Udeaja, C.E., Kamara, J.M., Carrillo, P.M., Anumba, C.J., Bouchlaghem, N. (Dino) and Tan, H.C. (2008), “A web-based prototype for live capture and reuse of construction project knowledge”, Automation in Construction, Vol. 17 No. 7, pp. 839-851.

Ulrich, K. T. (1995), “The Role of Product Architecture in the Manufacturing Firm”, Research Policy, Vol. 24 No. 3, pp. 419-440.

Voss, C., Tsikriktsis, N., and Frohlich, M. (2002), “Case research in operations management”, International Journal of Operations and Production management, Volume 22 No 2, 198-219.

Wikner, J. and Rudberg, M. (2005), "Integrating production and engineering perspectives on the customer order decoupling point”, International Journal of Operations and Production Management, Vol. 25 No. 7, pp. 623-641.

Yigit, A. S., Galip-Ulsoy, A. G., and Allahverdi, A. (2002), “Optimizing modular product design for reconfigurable manufacturing”, Journal of Intelligent Manufacturing, Vol. 13 No. 4, pp. 309316.

Yin, R. (2009), Case Study Research: Design and Methods, Sage Publications, Thousand Oaks. 
Zabihi, H., Habib, F. and Mirsaeedie, L. (2013), "Definitions, concepts and new directions in Industrialized Building Systems (IBS)”, KSCE Journal of Civil Engineering, Vol. 17 No. 6, pp. 1199-1205. 